\title{
TITLE:
}

\section{GOVERNING OF LAND SUPPLY IN BULGARIAN FARMS}

$\operatorname{AUTHOR}(\mathrm{S})$ :

Bachev, Hrabrin; Kagatsume, Masaru

\section{CITATION:}

Bachev, Hrabrin ...[et al]. GOVERNING OF LAND SUPPLY IN BULGARIAN FARMS. 京都大学 生物資源経済研究 2005, 10: 71-94

ISSUE DATE:

2005-03-25

URL:

http://hdl.handle.net/2433/54308

RIGHT: 


\title{
Governing of Land Supply in Bulgarian Farms
}

\author{
Hrabrin Bachev* and Masaru Kagatsume**
}

フラブリン・バチェフ、加賀爪 優「体制移行期のブルガリアにおける装地 取引の状況とその規定要因」.

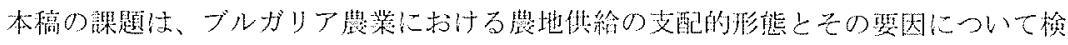
討することである。その際、体制移行期の路業経济の分析に、新制度経济学および取引

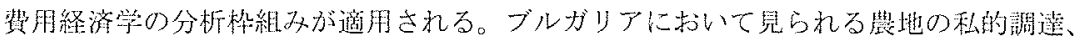

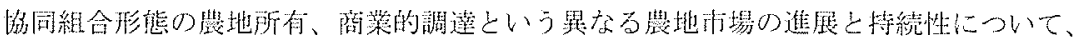

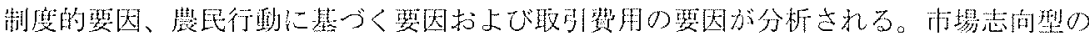

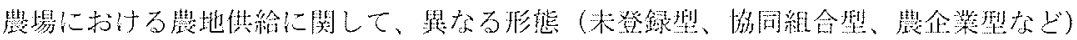

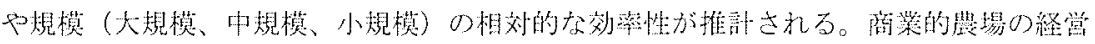
主から鳃取されたミクロ経济データに基ついて梌討した。

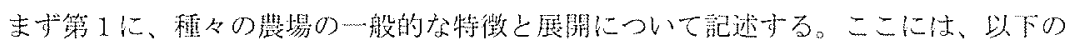

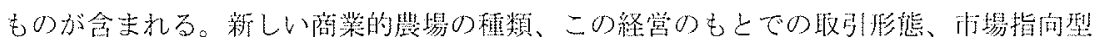

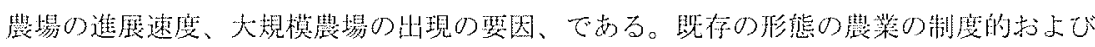
取引雚用面での䙺定要因が強調される。

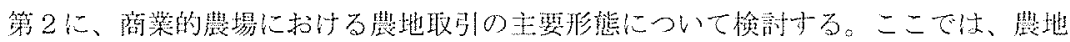

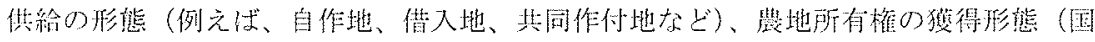

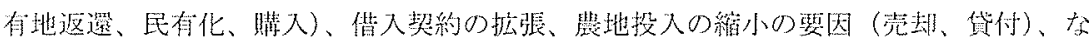

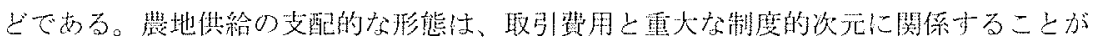
解明された。

第3に、土地供給における取引費用が分析される。以下のものが念まれる。土地供給 契約の国有の特徽、地代の形態、土地取引における第三者介入の程度、おょび地供給

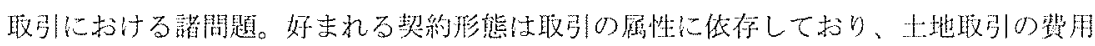
を最小化し保護することを意図している。

最後に、ブルガリアの蹗場の㹡大に刘する䙺定要因在特定化する。土地供給の減少上

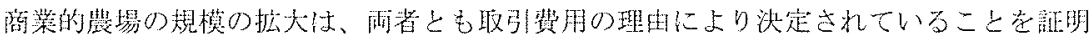

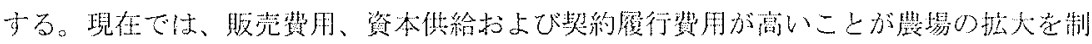

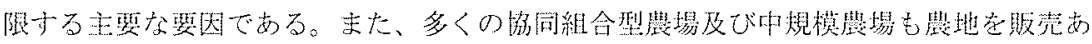

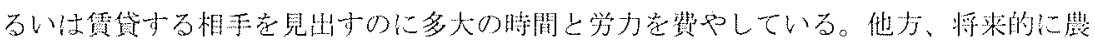

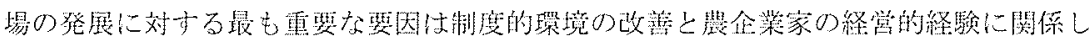
ている。㖘業経営主によれば、土地供給そのものに関しては、農場発展を阻害する固有 の琵因は無い。

\section{Introduction}

There has been fundamental transformation of Bulgarian farming structures since 1990 when transition to a market economy started. Large public farms have been liquidated or privatized. A new private farming has evolved, and agricultural land market has emerged. In addition, new

*) Institute of Agricultural Economics, Sofia, Bulgaria（ブルガリア国立宸鄴経济研究所）

**) Kyoto University, Kyoto, Japan（京都大学贯学研究科） 
kind of land tenure has developed (Bachev 2000, OECD). Currently, there are around 40000 commercial farms in the country (Ministry of Agriculture and Fishery, 2003). Most of them $(87 \%)$ are unregistered farms, averaging 1.8 ha and cultivating $19 \%$ of the farmland. Cooperatives accounts for $7.5 \%$ of the farms, have an average size of 600 ha, and manage around $43 \%$ of the total land. Agro-firms comprise $5.5 \%$ of the farms, cover $23 \%$ of the farmland, and have a size of 340 ha. In addition, there are more than a million subsistent farms cultivating around $15 \%$ of the total agricultural land.

Despite all that unprecedented development there has been no large-scale studies on governing modes and microeconomic factors for land supply in Bulgarian farms. All existing studies are at "theoretical" level, or based on unreliable and scare official data. Moreover, traditional "Neoclassical Economics" framework dominates in analyses of various agrarian organizations. Consequently, the character of real mechanisms that govern land supply is little known to academic community, policymakers, and public at large.

The New Institutional and Transaction Cost Economics is a new developing powerful methodology, which helps better understand the different modes for organization of agrarian activities (Bachev and Tsuji 2001a, Williamson). According to this novel approach the choice of one form for governing of land supply will depend: firstly, on institutional environment - existence of real private property rights on farmland, rights of private contracting, and efficient system for enforcement of individual rights and contracts. And secondly, on level of transaction costs of available (and practically possible) alternative modes for organization of land supply.

There is a spectrum of possible modes for land supply - use of own land, purchase of land, lease-in contract, cooperation etc. Among the feasible alternatives (such as trade, lease contract, employment contract, joint venture), the "rational" landlords and farm entrepreneurs will tend to chose the most effective mode to govern their relations - that form which maximizes benefits and minimizes costs of transactions. Furthermore, the effective size of farm ("farm economic boundaries") will be determined through optimization of the total costs for governing of land supply, labor supply, inputs supply, finance supply, and marketing. Agrarian agents will extend farm size with some form of land supply (ownership, cooperation, lease contract) only if it has comparative advantages to other modes for farm enlargement (through labor supply, capital investment, vertical integration etc.). Relative level of transaction costs will depend on behavioral characteristics of agrarian agents (such as bounded rationality, tendency for opportunism, trust, reputation consideration) and on critical dimensions of each transaction (such as appropriability, asset specificity, uncertainty and frequency).

In this paper an attempt has been made to identify dominant forms and factors for land supply in Bulgarian farms. It is a continuation of our previous efforts to apply the New Institutional Economics framework into analysis of governing structures in Bulgarian agriculture (Bachev and Kagatsume 2002, 2003). The study is based on original data collected from the managers of $0.5 \%$ of the commercial farms in the country. Surveyed farms have been selected as "typical" representatives for respective regions of the country. 


\section{Characteristic and Development of New Farms}

\section{1 Type of market-oriented farms}

More than $38 \%$ of surveyed farms are unregistered "individual, family, or group farm", almost $29 \%$ are "cooperatives", and one-third has a status of "firm". Questioned farms self-determined themselves as following: more than $45 \%$ are "middle size" farms, a little bit more than $38 \%$ are "small" farms, and merely $16.5 \%$ are "large" farms".

Various types of farms differ substantially according to size of transactions under their management (Figure 1). Most of individual, family or group farms organize transactions with relatively small scale, and there are no big farms among this group. Half of cooperatives govern transactions with middle-size and every forth is a large one. More than two-third of firms are with middle scales as share of big firms is also significant.

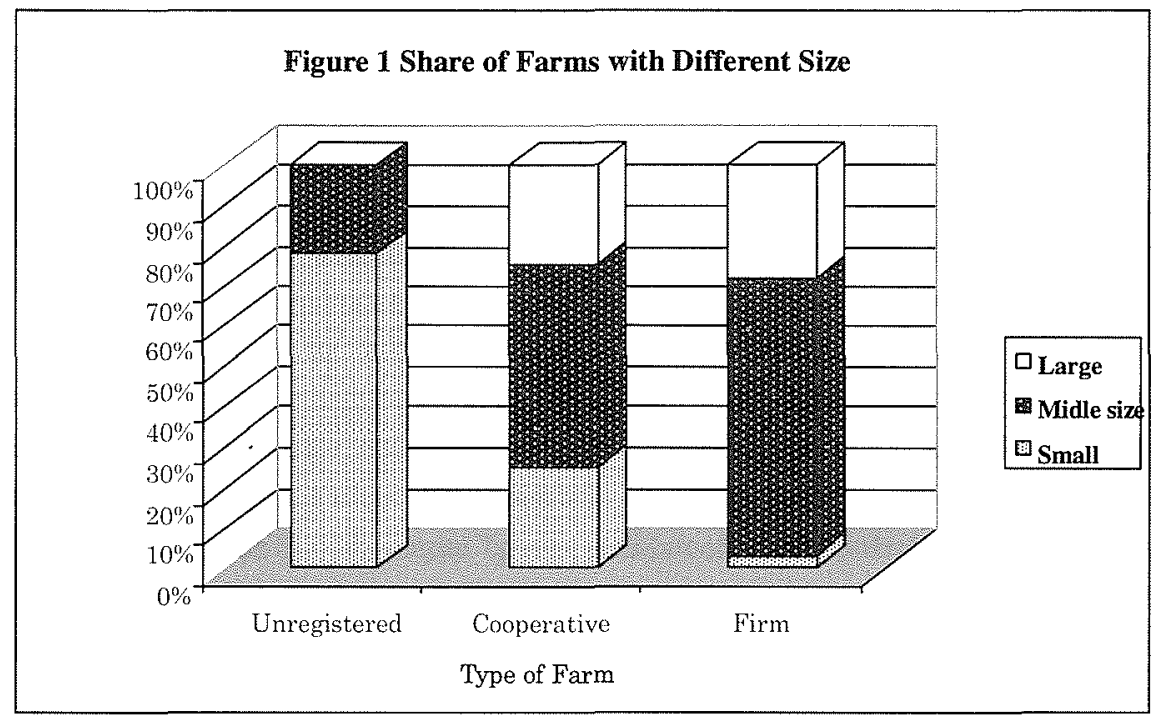

Source: personal interviews

Almost all surveyed farms organize transactions associated with crop production as every registered and bigger-size farm is engaged in such transactions (Table 1). Crop producing transactions take a major share in the product of all crop farms. Smaller farms reports that they are specialized in vegetables, fruits, tobacco etc. while bigger farms are mostly engaged in cereals and sunflower. Therefore, existing variation in farm sizes are greatly determined by the effective managerial possibilities in accordance with specificity of technology and product. For livestock transactions, the smaller and unregistered farms happen to be the more effective forms for organization than bigger and cooperative farms. Some cooperatives have more diversified structure (orchard, vineyards, horticulture) which is affected by member's needs rather than profit-making motifs. 
Table 1 Production Structure of Different Kind of Farms (percent)

\begin{tabular}{|l|c|c|c|c|c|c|c|c|}
\hline \multirow{2}{*}{$\begin{array}{l}\text { Kind of } \\
\text { farms }\end{array}$} & \multicolumn{3}{|c|}{ Share in total number of farms } & \multicolumn{4}{c|}{ Share in total farm product } \\
\cline { 2 - 9 } & Crop & Livestock & Meadows & Services & Crop & Livestock & Meadows & Services \\
\hline Unregistered & 86.49 & 59.46 & 2.70 & 13.51 & 66.59 & 62.73 & 10.00 & 16.00 \\
Cooperative & 100.00 & 50.00 & 10.71 & 42.86 & 72.32 & 37.50 & 40.00 & 10.83 \\
Firm & 100.00 & 62.5 & 15.63 & 62.50 & 63.00 & 37.25 & 20.00 & 13.30 \\
\hline Small & 86.49 & 67.57 & 0.00 & 16.22 & 60.81 & 62.60 & 0.00 & 15.00 \\
Middle size & 100.00 & 56.82 & 11.36 & 45.45 & 69.80 & 33.60 & 28.00 & 11.80 \\
Large & 100.00 & 37.5 & 25.00 & 68.75 & 72.19 & 40.83 & 22.50 & 13.64 \\
\hline Total & 94.85 & 57.73 & 9.28 & 38.14 & 67.09 & 47.32 & 25.56 & 12.86 \\
\hline
\end{tabular}

Source: personal interviews

There is also a tendency for integration of crop production in livestock farms of any kind. Incorporation of different activities under a single management (the same farm) is often conditioned by the necessity to secure "critical" for the livestock production forage supply. Many small farms protect these transactions through another private mode outside farm gates (group farming, cooperative). Not rare integration of different activities is a result of more effective intra-farm utilization of free resources (land, labor, equipment) comparing to outside trade of such resources (lease out or sell of the land; offering of labor or livestock service etc.). Finally, the diversification of activity is a mean for overcoming the risk of high market uncertainty (in demand and price fluctuation of livestock products) or institutional instability (Government support policy for different agrarian sub-sectors, international trade regime for food products etc.).

Less than one tenth of surveyed farms are occupied with maintaining of meadows, and those are mainly cooperatives and firms, and middle-size and large farms (Table 1). However, organization of this activity provide for more than a quarter of the products of respective farms. Share of maintenance of meadows is higher in cooperative and middle-size farms. Cooperative form allows realization of size economies from related to "individual" livestock production activity (which hardly can be explored in the small-scale livestock farms). Middle-size farms on the other hand, let effective operation of meadows (exploring technological economy of scale, specialization, sustainable use etc.) without higher management costs inherent to cooperative and large farms.

A good part of registered and bigger farms take part in service providing transactions (Table 1). Agrarian services occupy an insignificant part of the product of service supply farms. Thus involvement in this kind of transactions is associated with utilization of free equipment and labor rather than with investment in specific assets for organization of agrarian services. In these instances, it is equally unprofitable (high transacting costs) both: the trade of temporally free resources (leasing out of equipment and machinery; selling out labor), and further specialization in services (service trading). 


\section{2 Evolution of new commercial farming}

Emergence of private farming in the country started in1991 when restitution of agricultural lands and reorganization (transformation, privatization, liquidation) of ancient public farms were initiated. All surveyed crop farms are established before 1998 (figure 2). Greatest part of them started to organize land supply transactions before 1993, when most of the farms were set up. Process of expansion of new farms continues up to 1995 along with restitution of agricultural lands and liquidation of former cooperative farms ${ }^{2}$

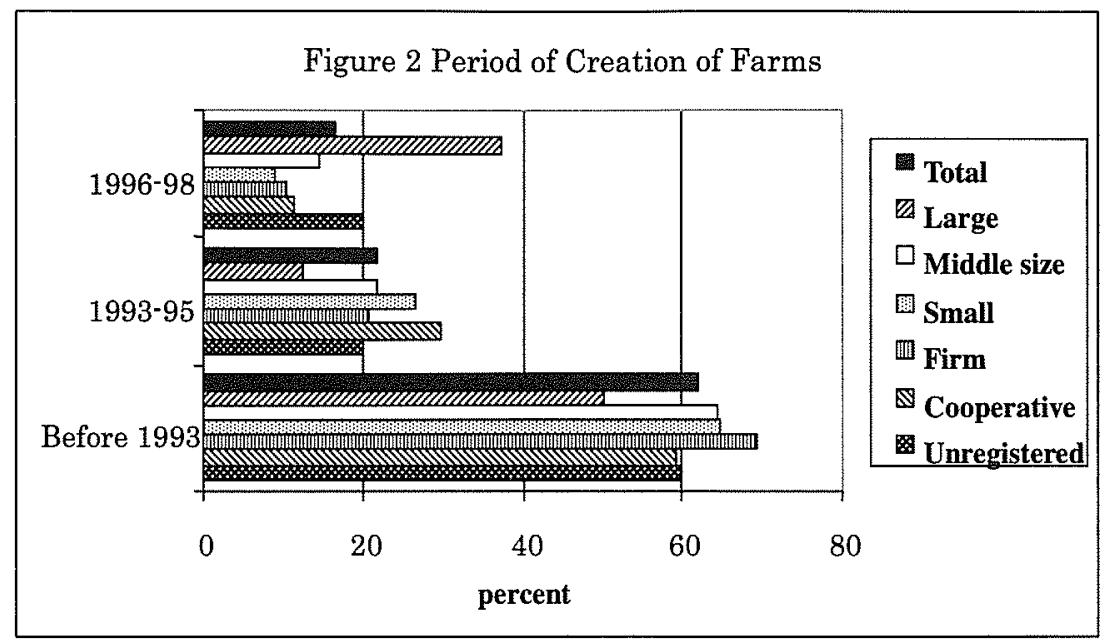

Source: personal interviews

Production cooperation is one of the "phenomenon" of transitional Bulgarian agriculture. The cooperative has often been the single form for farm organization in the absence of settled rights on farmland and agrarian resources and/or inherited high interdependence of acquired by individuals assets (Bachev 2002). More than 2 millions Bulgarians have got individual stakes in the assets of liquidated ancient cooperatives. In addition to their small size, a great part of these shares were in indivisible assets (large machinery, buildings, processing and irrigation facilities). Therefore, new owners had no any alternative but liquidate (sales, consumption, distortion) or keep them up as a joint (cooperative) ownership. In many cases, ownership on farmland was restituted with adjoined fruit trees and vineyards, and much of activities (mechanization, plant protection, irrigation) could be practically executed solely in cooperation. Most of landowners happened to live away from rural areas, have other business, be old of age, or possess no skills or capital to start own farms. In the absence of big demand for farmlands and/or confidence in emerging private farming, new evolving cooperatives have pulled land plots of more than $40 \%$ of novel proprietors.

The cooperative rather than other formal collective mode (e.g. firm) has been mostly preferred. It allows individual members to enter and exit easily and with low costs from coalition, preservation of full control on a major private resource such as land, and democratic participation in (and control on) management. Besides, cooperative form gives some important tax 
advantages such as tax exemption on sale transactions with individual members and on received rent in kind. Also there are possibilities for organization of transactions, which are not legitimate for other modes - e.g. unlimited lease-in of farmland; and credit supply, marketing, and lobbying at nation-wide scale ${ }^{3}$. Moreover, most of cooperatives develop along with (or after) emergence of small-scale and subsistent farming. Namely, "non-for-profit" character and strong member (rather than market) orientation attracted membership of many households. Production coops have been perceived as an effective (cheap and stable) form for supply of highly specific to individual farms inputs and services (e.g. forage supply for private animals; mechanization service for subsistent and small farms; storage, processing, and marketing of farm output), and/or food for household consumption.

Our survey proves that during 1996-98 less cooperatives and firms were formed but the share of emerged large farms is significant. That is a consequence of the progress in conditions for transfer of rights on agricultural land (completed restoration of property rights, regulation of tenancy, development of land markets) and augmentation of competition. Improvement of institutional environment diminishes transaction costs for land supply and promote land concentration up to optimal (larger) scales. Competition pressure on the other hand, makes transfer of land management into more-efficient (and as a rule bigger) structures imperative for existence of crop farms.

Share of farms extending land supply transactions increases throughout the period but the percentage of farms with a growth in cultivated land is especially big after 1993 (Figure 3). While in agrofirms the process of expansion is typical for entire period, unregistered farms enlargement is particularly significant after 1993. Portion of cooperatives with increasing cultivated land is relatively high during 1993-96, and one out of three expands land supply after 1996. Therefore, all structures in crop production tend to extend farm boundaries through additional land supply. Besides, a substantial part of small and medium-size and big farms enlarge cultivated land since 1993. All these prove that amelioration of institutional framework and competition cause a gradual selection of less effective forms and transfer of land management to more productive farms up to the optimal (for relevant sub-sectors) scale.

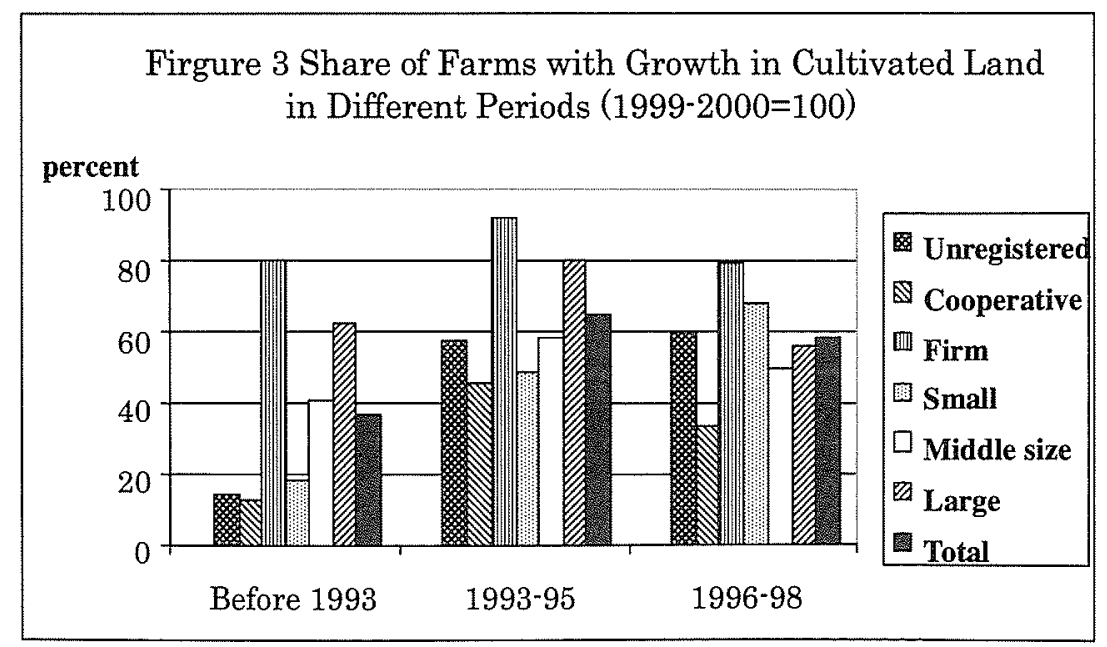

Source: personal interviews 


\section{3 Subsistent farming}

Subsistent farming has been one of the immanent features of transitional Bulgarian agriculture. According to different data, subsistent farms comprise 0.72-1.5 million and cultivate a good portion of the total farmland in the country (National Statistical Institute, Ministry of Agriculture and Fishery). That specific mode of farm and land organization has been dominating for 14 years now having a significant importance for household and national economy.

Agrarian reform (1991) has turned every other Bulgarian household into an owner of farmland, livestock, equipment, etc. Internal organization of available household resources in an own farm has been an effective way to overcome the great institutional and economic uncertainty, and minimize the costs of transacting (Bachev and Tsuji 2001b). Firstly, private rights on most of farmlands were not entirely restituted until 2000, which made market trade with land very difficult or impossible at all. Besides, there was "oversupply" of farmland and the effective demand was not immense. Next, many Bulgarians have lost their jobs as a result of privatization of public farms and industrial companies. Large majority of people have been at pre-retired or retired age and had no other job alternatives. For others farming has been a stable "temporary" or second employment in conditions of high insecurity of job market. Therefore, starting up an own farm has been the most effective (or only) mode for productive use of available "free" labor and farmland. "Diversification" into farming has taken place and now farming is an "additional income source" for almost 1 million Bulgarians or $72 \%$ of the "engaged persons in agriculture" (Agrarian report, 2003).

In transitional conditions market or contract trade of household's capital (land and labor) has been either impossible or very expensive - high uncertainty, asymmetry of information, and risk; big possibility for opportunism in time of hardship. Moreover, low payoff of outside trading has been combined with an increased share of food costs in household budgets. Therefore, internal organization has turned to be the most effective way to protect and get return on resources, and to secure stable income. The long-term tradition with "personal plots" during the communist period, and the insignificant costs for acquiring specialized knowledge (information, training, learning by doing experience) has made initiation and development costs for own farm accessible for everybody. In addition, there has been a great (price, quantity, quality) uncertainty associated with market supply of basic foods (many new suppliers, no reputation built, poor assortment, insufficient enforcement of quality standards). For lots of consumers an internal organization (own production) has been an effective mode to guarantee cheep, stable, safe, and high quality delivery of food. Besides, for many Bulgarians farming activities happens to be a preferable full-time or free-time occupation. For the same reasons, a considerable part of commercial farms use output for household consumption having a good share of total product "marketed" into extended households (Table 2). That is how, a highly sustainable form of subsistent (and semi-subsistent) farming and land supply has developed in the country. According to non inclusive official data, the share of "own consumption" in the total farm output in Bulgaria is $67 \%$ for beans, $55 \%$ for pumpkins, $49 \%$ for wine, $45 \%$ for potatoes, $35 \%$ for melons and water melons, 33\% for pears, $22 \%$ for other fruits, $17 \%$ for tomatoes, etc. (Agrarian Report for 2003). 
Table 2 Share of Commercial Farms with Output for "Own and Family Consumption, and Giving to Relatives and Friends" (per cent)

\begin{tabular}{|l|c|c|}
\hline Kind of farms & $\begin{array}{c}\text { Share of farms using output for } \\
\text { household consumption }\end{array}$ & $\begin{array}{c}\text { Share of output in respective } \\
\text { farms for household consumption }\end{array}$ \\
\hline Unregistered & 81.08 & 18.57 \\
Cooperative & 46.43 & 12.46 \\
Firm & 43.75 & 20.79 \\
\hline Small-size & 86.49 & 20.09 \\
Middle-size & 40.91 & 16.78 \\
Large & 43.75 & 9.29 \\
\hline Total & 58.76 & 17.72 \\
\hline
\end{tabular}

Source: personal interviews

\section{Modes of Land Supply in commercial Farms}

\section{1 Types of land supply}

There is a significant distinction in forms for land supply in different kinds of farms (Table 3). Ownership is the major governing mode for most of individual, family and group farms.

Table 3 Structure of Cultivated Land in Different Kind of Farms (percent)

\begin{tabular}{|l|c|c|c|c|c|c|}
\hline \multirow{2}{*}{ Kind of farm } & \multicolumn{3}{|c|}{ Share of farms with: } & \multicolumn{2}{|c|}{ Share in total cultivated land of: } \\
\cline { 2 - 7 } & $\begin{array}{c}\text { Owned } \\
\text { land }\end{array}$ & $\begin{array}{c}\text { Leased } \\
\text { land }\end{array}$ & $\begin{array}{c}\text { Cultivated } \\
\text { in group }\end{array}$ & $\begin{array}{c}\text { Owned } \\
\text { land }\end{array}$ & $\begin{array}{c}\text { Leased } \\
\text { land }\end{array}$ & $\begin{array}{c}\text { Cultivated } \\
\text { in group }\end{array}$ \\
\hline Unregistered & 81.08 & 51.35 & 13.51 & 59.07 & 82.78 & 55.00 \\
Cooperative & 32.14 & 92.86 & 25 & 30.00 & 85.77 & 42.86 \\
Firm & 59.38 & 93.75 & 3.13 & 25.00 & 89.50 & 40.00 \\
\hline Small & 82.35 & 58.82 & 14.71 & 61.43 & 79.25 & 83.00 \\
Middle size & 57.14 & 92.86 & 11.9 & 24.25 & 93.28 & 36.00 \\
Large & 37.5 & 100 & 18.75 & 35.83 & 79.06 & 40.00 \\
\hline Total & 63.04 & 81.52 & 14.13 & 43.40 & 86.51 & 47.31 \\
\hline
\end{tabular}

Source: personal interviews 
More than a half of unregistered farms use lease-in contract for land supply, and only insignificant number of them practice group cultivation. Around one-third of cooperative has own land, every forth practices group cultivation, and most of them use leasing. Share of agro-firms with owned land is big, but a great part of these farms rely on leasing for extension of their size. Only a small portion of firms resorts to group cultivation.

There is a tendency with enlargement of farm size to decrease the share of owned land and to increase the share of leased land. Portion of owned land is relatively high only in unregistered and small farms. Leased-in land comprises not less than three-forth of the total cultivated land of tenant farms. Hence, lease contract has been the main form for extension of cultivated land in Bulgarian farms.

Group cultivation is practiced by farms with different sizes. Portion of jointly cultivated land constitutes the main share of total land in small farms, while this part is also significant in medium and large farms. In many instances, this mode of governance is associated with a number of advantages to intra-farm cultivation, for example, it either gives opportunity for "group" exploration of technological economies of scale and size (equipment, operations etc.) unachievable within individual farm; or it is combined with some transacting benefits for individual farms such as protection of dependant assets, access to outside credit, economy on management and overhead (e.g. for security guards) costs etc.

\section{2 Acquisition of land ownership}

Until the end of Communist period there was no real private ownership on agricultural land in Bulgaria. Since 1991 institution of private property has been restored and agricultural land restituted to previous owners or their heirs". Nearly all "new" land owners have set up some kind of private farms (subsistent, commercial, cooperative etc) ${ }^{5}$. Major form for acquisition of land property in all types of surveyed farms is "ownership restoration, inheritance, or getting as a present" (Figure 4).

Process of restoration of private property rights on land has been very slow and not completed until 1999. Consequently, sells market for agricultural land has started to develop just recently. One-forth of surveyed farms has acquired ownership on agricultural land through "purchase" as share of large farms participated in such transactions in significant. Few privatization deals on state and municipal agricultural land have been also carried out in recent years. Only $7 \%$ of surveyed farms have got land ownership through "privatization".

Acquisition of ownership rights (purchase of land) is an alternative form for land supply to lease transactions (buying only the "cultivation rights"). This mode for supplying of necessary land is associated with significant capital investments (for paying of land price, for preparation of papers and formal registration of deals), and efforts (for finding good land plots, for checking out and securing purchase provisions etc). Besides, it allows low flexibility for optimization of farm size through reallocation of land plots or quick emergency sell. Despite this, it is often a preferable mode since it gives a reliable protection of long-term investments in land against possible opportunism of outside landlord (e.g. termination of lease contract before the end of effective life-span of invested capital). Our survey proves that land supply trough procurement of 


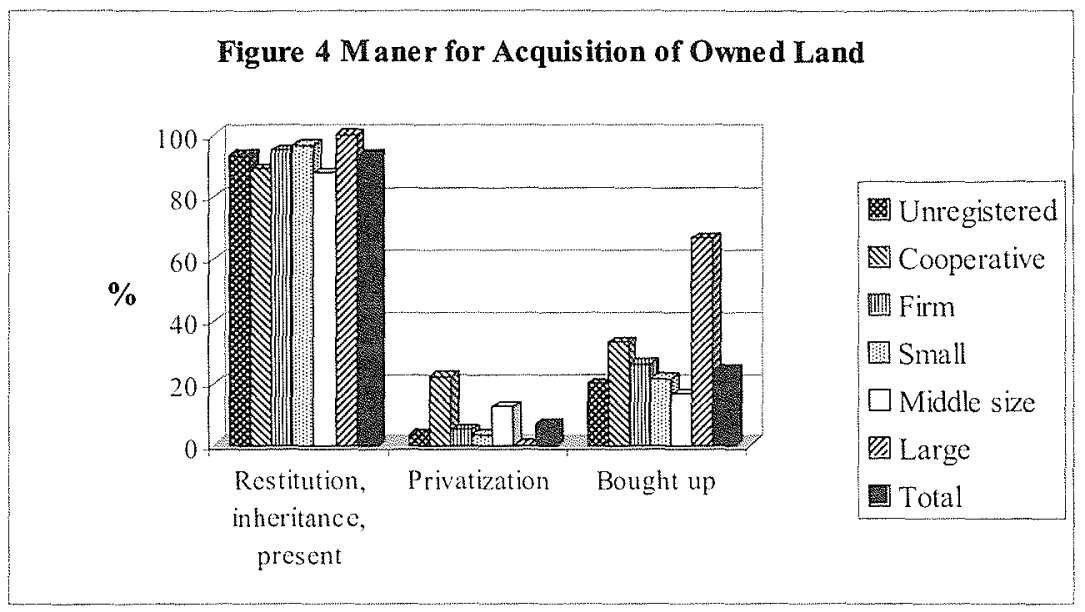

Source: personal interviews

ownership governs transactions only if there is condition of high mutual (or unilateral) dependency of assets with adjoint land plots. All farms applying this mode indicate using purchased land for buildings, orchard and vineyard, irrigation or other long-term amelioration of land. When there is no assets dependency or cite-specificity of investments to the land is insignificant, then either short lease or middle-term lease-in contracts are the most effective forms for extension of farm operations (less capital intensive or one year crop).

All surveyed farms participate either "never" or "rare" in purchase transactions for agricultural land. It means that costs for land supply through purchase mode are insignificant. Besides, more than a half of farms carry out purchase deals with "relatives", and these transactions are facilitated by close relationships, confidence, and cooperation between partners. Typical partners for the remaining farms are "non farmers". Similarly, such deals are not associated with high costs for professional farmers since they can easily determine the real value of traded land parcels; and thus selling non-farmer can not practically behave opportunistically; and agricultural land does not poses a special value for non-farmers, and they tend to complete deals fast according to the existing market norms.

Finally, frequently land purchase transactions are either "always with the same partner" or "often with the same partner". Multiple relationships between the same counterparts permit their mutual acquaintance, develop trust, restrict opportunistic behavior, and minimize overall transacting costs.

\section{3 Lease-in contract}

The lease-in contact is an alternative form of land supply to the purchase of land. For surveyed farms, this has been the dominant form for farm extension through integration of new land plots. One of the reasons for preferences to this mode for organization of transactions is the unsettled property rights on farmland (lack of notary certificates, uncompleted land division process, disputed rights between claimants etc.). Indeed, since the beginning of transition until 2000 , due to unsettled or incompletely restituted ownership rights on land, the short-term lease 
was the only possible form for organization of land supply in Bulgarian farms (Bachev 2002).

Another principal factor for domination of this form for land supply is its comparative efficiency for the individual farm: Firstly, land lease requires less direct investment in comparison with a land purchase. The economy on capital investments has been a crucial factor for preferences to this mode in the transitional conditions of significant lack of own funding, and extremely high costs for credit financing, and absence of public programs for land procurement? Secondly, this form allows greater flexibility for rapid optimization of farms size along with current market and technological changes (e.g. quick inclusion or exclusion from operation of needed land plots). Thirdly, it permits inexpensive verification ("production test") of real values of a particular land for the certain farm. Thus it restricts the risk in case of bad deals (e.g. unsuitable partners or land plots) to the period of lease contract. Forthly, in some instances (e.g. mono culture) that is the best form for annual (or seasonal) supply of divers new land plots to any alternative modes (such as purchase, exchange, group farming, crop rotation).

Continuous land supply through a lease mode increases relatively the costs of transactions. This is determined by: the high recurrence of deals for supply of a particular amount of land (needs for renegotiations deals for the same plots after end of each lease contract), and costs for resolution of possible conflicts with land owners etc. However, these expenses are negligible comparing to additional benefits of this governing form. Here market for short lease (competition) and long-lasting relationships between counterparts regulate satisfactorily transactions. However, when significant farm-specific long-term investments in land are to be made (longterm improvement, permanent tree, building etc.), then a special form is designed to safeguard land supply from possible opportunism of partner (use of long-lease contract, acquisition of ownership, joint venture with landlord etc.).

More than $70 \%$ of surveyed farms participate "very often" or "often" in lease-in transactions, including nine out of ten cooperatives, three third of firms, and more than a half of unregistered farms. As a rule, almost all large farms, most of middle-size farms, and a good part of small farms are involved intensively in this kind of land supply transactions. Typical counterpart in lease deals are "relatives", "well-known" or "unknown farmers". However, share of agents not related to farming is also significant - for instance "non-farmers" are $21 \%$, and "State and municipalities" - 12\%. Recurrence of deals between same partners is big. Hence for all leasing farms the overall expenditures for carrying out contracts are not high. Besides, almost one-third of lease-in contracts are with relatives and familiar farmers, as mainly personal (rather than anonymous market) relationships govern transacting. The later form, based on personal ties, is preferred since it permits an efficient information exchange (in respect to demand and supply, partners reliability), cooperation in contracting and dispute resolution, and low cost control (selfcontrol) in meeting contract terms. Leasing larger and cooperative farms are often provider of job and services for landlords. These additional interlinks diminishes opportunistic behavior in land deals. 


\section{4 Deals for reduction of land supply}

Portion of farms which sell-off land increases since 1995 but it is still at a very low level of $3.3 \%$. Until 1998 predominantly unregistered farms sell land, and those are mainly small and medium-size farms. During this period restitution of agricultural land had been sill carrying out and an optimization of farm size had been taking place through transfer of land to bigger farms. In recent years, two-third of sells deals are executed by the cooperatives and larger farms. Land management is already concentrated in big farms and part of them use land sells as a means for scale optimization. On the other hand, small and middle-size commercial farms are on the expansion phase, and therefore they have not been involved in sell transactions.

Prevailing part of farms participates in land sells transactions either at the frequency of "rare" or "not at all". Around 13\% of farms however, sell "very often" or "often" land. Those are onefifth of cooperatives and a portion of other farms as sellers are entirely with small and middlesizes. For individual, family and group (and in this case relatively small) farms the buyers are only "relatives". Typical partners for selling firms are "unknown farmers" and exclusively "non farmers" for the cooperatives. In more than $90 \%$ of instances counterparts either are not changed or they are often the same agents. All of these indicates that level of transaction costs for such repeated (between same partners) deals are insignificant.

Selling of the cultivation rights (lease-out) is an alternative form for selling-off the land property (all "residual" rights). One of the reasons for domination of this mode has been the lack of full ownership rights on land (incomplete process of land restitution), and therefore a practical possibility for complete trade with changing of ownership titles. Another main reason however, is the condition of some specificity (dependency) between the temporally free land and other farm assets (e.g. adjacent plots, accomplished improvements etc.). This is why, business farms tend to transfer management but lose entire control (full ownership rights) on such lands. In the long run, these plots are indispensable for optimization of farm size.

The alternative form for leasing out of (owned) land is the internal organization of transactions through utilization of available land within the farm, investing additional capital, hiring additional labor etc. Manager prefers to lease the land-out to another farm instead of organizing new operations within own farm (on available land) because of comparative advantages of this governing mode. Internal management of a particular land plot would increase farm income, but it would be associated with augmentation of management costs for additional transactions. For example, it would require supplementary efforts for hiring, directing, and monitoring of labor; extra efforts to find working and investment capital; additional cares for protection and marketing of farm output etc. This is why, instead of internal organization the manager prefers much cheaper outside "land supply" (lease-out mode). In this case, either he reduces farm size or extends farm with land saving transactions (e.g. intensive crops, livestock operations, processing etc.).

Manager's transacting costs for lease-out plots are limited to finding a partner, negotiating, and controlling contractual terms. Those are exclusively costs for managing land property rather than costs for organizing farming activity (which are actually brought by tenant). Generally, there are economic or another incentives for preferring the form of temporary transfer of 
cultivation rights in contrast with selling out of "excessive" (for farm) land. As our surveys shows, those are the plans for farm extension in future; desire to keep up an emergency reserve from owned land; expectation for appreciation of value of a particular land plot; special ("traditional") respect to farmland and desire to keep in for future generations etc.

Share of farms leasing out land has increased three times comparing to the period before 1993, and now more than one-fifth of surveyed farms are involved in such transactions. Only few unregistered and small farms practice this mode for optimization of resources. Reduction of farmland through lease takes place only after 1996 in 13\% of cooperatives. For agro-firms, large and middle-size farms, leasing out turns to be the main form for optimization of size of cultivated farmland. Namely, these farms are highly sensitive to market signals and tend to manage their resources according to efficiency rule.

Predominant part of surveyed farms either does not take part in land lease-out transactions or they do it rarely. Solely share of cooperative farms, involved in this kind of transactions, is higher - $45 \%$, including $22 \%$ which do it "frequently". This finding is surprising since the goal of a producer cooperative is to farm instead of trading (profit on) members land". Apparently, cooperatives have a number of extra advantages in carrying (mediation of) land transactions between owners and tenants in comparison to other modes (direct trade; using of market agent or state agency). We have found that such advantages are mainly associated with: scale economy on this activity (information and operational costs), technical opportunity for consolidation and reallocation of land plots, authority and power to enforce land deals etc. This new "free service" (mediation of land deals) makes production cooperatives a specific and effective mode for governing of land supply in Bulgarian conditions.

Leasing out farms are mainly large-scale farms. Typical partners for the majority of farms are "well-known farmers" and "relatives". Preferences to such counterparts are determined by: minimal costs for collecting information for tenant reliability and his farming capability; facilitated contract enforcement and dispute resolution possibilities; implicit belief that a farmer would take care of leased land etc. Nevertheless almost one-forth of partners are not farming agents ("nonfarmers", "state or municipalities") who are either agrarian entrepreneurs, or use land for non agricultural purposes, or are mediators for consecutive leases.

For most of the farms frequency of lease-out transactions with a particular partner is high. This is caused by the lower costs for contract renewal in comparison with new contracting; stronger incentives for self-restriction of opportunistic behavior of tenant; opportunity to elaborate effective control and dispute resolution mechanisms etc. Nonetheless, a significant portion of lease-out contracts (43\%) is with low recurrence, and it is particularly true for cooperatives and firms. However, later farms often have other devices for preventing possible opportunism and careless utilization of land such as economic influence, strong regional authority and power, interlink transacting (e.g. land plus service supply) etc. 


\section{Transaction Costs for Land Supply}

\subsection{Type of land supply contracts}

Considerable share of land purchase and sell deals in surveyed farms are carried out through "written contract", which in most instances is "notary legalized" or "registered in agricultural office". To a great extent the written mode and formal registration of (changes in) ownership titles are determined by the official regulations. However, preferences to a paper form are usually strong when "residual rights" on such resource like land are transferred. This form provides a long-term legal protection of rights on an indispensable, an eternal, and often a highly specific to a farm asset.

Part of investigated farms report they use a "verbal agreement" as the form for accomplishing purchase and sell contracts - 21\% and 14\% accordingly. Informal transfer of ownership presumes a high trust between partners, and existence of reliable (informal) mechanisms for effective contract enforcement (e.g. family or friendship relations). In many cases, this mode assumes an unfinished (uncompleted) ownership transfer transaction. For examples, a land purchase is negotiated, but a payment is not made (due to shortage of cash, desire for a "trial" period); or actual utilization of land is undertaken, but partial payment, over several years, is in place. It is not an accident that latter form for ownership transfer is practiced by less stable and financially weak structures - unregistered and cooperative farms, and small and middle-size farms.

A good part of land lease-in deals and a significant part of lease-out deals are governed by "oral agreement" between partners - $28 \%$ and $45 \%$ correspondingly. Since mutual expectations of parties are to a great extent standardized, and contract terms well-defined and understood by counterparts, there is no need for written specifications of transactions. The economic value of different land categories in a particular region is generally well known (often "officially" determined). Therefore, a standard (market) rent reflects quality variations, and technological specificity are easily negotiated (e.g. situation of land plots, accomplished improvements etc.). Specificity of investment in agricultural land is low and mostly restricted to a season (one-year crops). Contract term is not of importance for either partners since transactions can be terminated any time (after each season) without significant loses for either parties. Agreement is reached easily and it is not difficult to enforce contract provisions (cares for land, rent payments etc.). Putting into a written form of standardized obligations has no sense, and all notary and formal registrations are only coupled with useless additional costs (efforts, fees payments etc.).

Formal lease contracts are used mainly by cooperatives, firms, and bigger farms. They are put to use because of the explicit legal requirements (as in the case of cooperatives) when violation of such institutional restrictions is easily discovered by authority. However, a major reason for selecting written and formally registered contracts is existence of considerable economic advantages for this mode of organization of transactions. Our surveys prove that, those are possible direct economies for big tenants (farms, firms, cooperatives) from applying standard contracts to numerous (usual small) land owners, and avoiding individual negotiations of universal transactions. Besides, these farms commonly practice a long-term lease and therefore realize economies form constant (annual) renewal of contracts after each season. And finally, formal contracts 
better safeguard pay-back of investment in leased-in land through a third-party (e.g. court) enforcement of agreements and against possible early termination of contracts. The latter is particularly important for large farms, which cultivate big land and consolidated plots investing significant capital with high farm (and land) specificity.

\section{2 Type of the rent}

In lease-in contracts around $43 \%$ of surveyed farms give preferences to "share rent". This portion is higher for unregistered and cooperative farms as well as for small and middle-size farms. "Fix-rent" is noticed as most desirable for the rest 30\% of the farms, as firms and large farms favor more this sort of rent. One-forth of farms use "mix rent" contract. For all farms the major factor for rent choice is "the specific product grown on land". Next important factor for rent selection is "good/bad relations with land owner". In the rent-formation process the firms and large farms use "as a base the dominant rent in region". Small and unregistered farms fix rent "through concrete negotiation". Cooperatives and middle-size farms apply equally both market and negotiated rent arrangement.

In lease-out contracts unregistered farms and firms, and small and large farms give a priority to prior rent fixing. Mix form is preferred by most of cooperatives and middle-size farms. Specific product grown on land is the most important factor for rent choice in firms and cooperatives, and medium farms. Unregistered and small size farms report as the main consideration "good/bad relations with a partner". "Economic stability/instability in the country" is a significant factor for all kind of farms, and the most important for the large farms. While majority of firms employ as a base predominant rate in the region, all cooperatives and nearly all of unregistered farms form rent through concrete negotiation.

Rent choice is important for minimization of overall cost for lease contract. When a fix rent is adopted a land owner saves the cost for controlling of tenants conscientiousness (in respect to efficiency of land use, and fair payment of negotiated share-rent). This mode also contains strong incentives for intensive exploitation of leased land since tenant keeps entire surplus product of his efforts. On the other hand, all risk in fix-rent contract is born by tenant-farmer. Generally, a great natural uncertainty (climate, diseases and pests attacks, yields) is coupled with big economic uncertainty (level of production costs, demand, output prices) in farming. Therefore, most of surveyed farms give a preference to shared or mixed-rent (some share participation in output) in lease-in deals. As land owners (in lease-out deals) the same agents favor fixed rent due to high uncertainty associated with transactions.

\section{3 Third-party involvement}

In land purchase deals majority of surveyed firms and unregistered farms, and a good part of cooperatives "do not use any mediator". However, more than $70 \%$ of coops use specialized private agents ("estate agency") or public agency ("Land Commission or Local Administration") in organization of these transactions. Almost $43 \%$ of unregistered farms resort to a third-party assistance in land purchase, and they rely mainly on "friends" or "estate agency". Only $18 \%$ of 
agro-firms use a mediator and this is exclusively "Land Commission or Local Administration".

In sell-off deals most of the unregistered and small farms employ no intermediary. Despite that one-quarter of them make use of private estate agency, and every forth rely on friend assistance in such transactions. Around $56 \%$ of cooperatives use mediation by a Land Commission, and each third counts on service by an Estate agency. All firms use a third-party in this kind of transacting, as in the most cases those are friends, estate agents, and Land Commission or Local Administration.

Along with the development of farm structures, an intensification of land ownership transfer is taking place. Smaller farms to a lesser extent are involved in such sort of deals due to the weak necessity for purchase-sell of land. Besides, these farms strongly rely on direct links with counterparts, while larger farms tend to use market forms (e.g. estate agencies). Along with progress of land market and intensity of land deals, there will be an increase (absolutely and relatively) in farm's costs for land supply. This will increase the numbers of ownership transfer transactions carried out by mediation of specialized private structures (agencies, brokers, exchanges etc.). Augmented size of land deals would be also a condition for development of various markets and private forms, which will be able to aggregate potential economies (size and scale) from land trade. Currently there are still significant difficulties in private and market organization of land transactions - unavailable information for lands and partners, small scale of land deals etc. This is why a public support (through information supply, assistance, direct involvement or control) of private and market transacting via different public agencies is of a great importance ${ }^{10}$.

As far as land lease-in deals are concerned, a predominant part of cooperatives and large farms do not use assistance of any intermediary. These farms are big and long-term lessors in a respective region, and their needs, leasing terms and reputation are well-known. This is why these farms need no mediation for their relationships with prospective land owners. More than two-third of unregistered and small farms either do not use a mediator or rely on friends aid for such transacting. Demand and supply of agricultural lands are strongly localized and they are well-known in agrarian communities. Previous reputation of farmers in regard to care and efficiency of (leased) land use, rent payments etc. are also well-recognized (transfer by "means" of mouth"). Besides, individual demands for land in small farms is not significant to make necessary and to justify (in respect to transacting costs) use of a special form or a middleman.

However, in many instances direct links between land owners and tenants are impeded, and a mediation of public structures is in place. Majority of agro-firms, a good part of unregistered farms, and one-fifth of cooperatives, all of them use help from Land Commission or Local Administration in these deals. Short duration, localized character, and low intensity of these transactions do not necessitate employment of a specialized private structure for mediation. Almost one-fifth of surveyed firms and a part of cooperatives report using "other" private (not personal or public) intermediary for lease-in deals. Most often those are business or other partners, which assist land supply deals in a "package" with other interlinked transactions (e.g. labor or inputs supply, marketing, another form for integration etc.).

In lease-out deals more than two-third of farms use no mediators or count entirely on friends' connections. Assistance of public body is used by less than a forth of farms. Every fifth of 
surveyed farms also mention "other" agents assisting these transactions, as share of large farms and firms applying such mediators is particularly big. This is again a sign for closer integration links with other business structures and emergence of various modes for interlinked organization of transacting.

\section{4 Problems in land deals}

Often smooth land transacting is interrupted by various problems, and dealing with such troubles (preventing, identifying, overcoming) gives rise to overall transacting costs for land supply.

In land purchase deals, solely one-third of surveyed farms "usually do not have any problems". Those are majority of cooperatives and firms, and most of the large farms. Immense regional power (major buyer, other dependency of sellers) and authority (reputation, commercial experience, political influence) of these farms facilitate collaboration of their counterparts and speed up conflicts resolution. Besides, these farms have better experience in carrying out such deals, which minimize their costs for new purchases (high frequency, foreseeing and preventing possible problems).

However, the prevailing share of farms encounters problems in purchase transactions and are making costs for overcoming associated difficulties. Most of unregistered farms and firms, and relatively small farms, practice (prefer or forced to) "hire a lawyer". Part of coops applies also "additional negotiation", and some of unregistered farms resort to "other measures" of unregistered farms and $15 \%$ of cooperatives report that they "can often undertake nothing" for resolving the problems. Consequently, latter deals either do not take place or are not carried out according to wishes, expectations, or agreements of parties. Generally, any augmentation of transaction costs prevent otherwise effective and mutually beneficial transactions to take place.

In sell-off deals more than a forth of farms usually do not confront any problems. Majority of unregistered farms, cooperatives, and small farms hire lawyer for solving problems in such deals. Most of cooperatives, firms, and large farms practice "additional negotiation" for facilitating transactions. One-third of firms look for resolution of conflicts "directly in Court", and some employ "other measures". More than $14 \%$ of unregistered farms with a middle-size report that they often can undertake nothing to settle disputes.

In lease-in deals, around $30 \%$ of farms generally meet no problems. Majority of unregistered farms and firms resolve difficulties through additional negotiation. In problematic situation the cooperatives usually hire a lawyer. More than one-fifth of agro-firms turn to solve their disputes directly to Court or use mediation by a lawyer. According to nearly $15 \%$ of all farms (including every fifth of unregistered and cooperative farms) they are commonly able to do nothing to settle their problems in these transactions.

In lease-out deals lack of any problems is a typical situation for merely one-third of unregistered farms, and for negligible part of remainder farms. Supplementary negotiating for smoothing over conflicts is practiced by all kinds of farms. Part of firms and cooperatives seek direct assistance in Court for dispute resolution. When having transacting problems a good part of firms apply "other measures" as well. Half of cooperatives, every third of unregistered farms, and more than $26 \%$ of firms put in place "waiting strategy". They hardly can undertake 
anything for conflict resolution and "save" action costs in this respect. In latter case, transactions either break down (deal is not carried out) or it is waited for termination of contract despite unacceptable lease terms.

\section{Factors for Enlargement of Bulgarian Farms}

\section{1 Reasons for reduction of land supply}

The most common reasons indicated for size reduction (through land sells-off or lease-out) in surveyed farms are: "lack of gain from land cultivation", "accumulation of funds for financing of other activities", "impossibility to manage all owned land", and "ceasing some activities". For unregistered and small farms the major factors for land sells are the low efficiency of land use and combination of production factors ("lack of gain from land cultivation" and "termination of some specific activities"). On the other hand, for cooperatives, agro-firms, and large farms with a great importance are the high land management costs ("impossibility to manage all available land") and organization of financing of farm activities ("mean for accumulating funds for financing of other activities").

All types of farms indicate as the major reason for leasing-out the "lack of benefits from land cultivation". For unregistered and small farms the "impossibility to manage all owned land" is also an important motif while for the cooperatives, firms, and bigger farms this is a "mean for financing of other agrarian activities".

All these prove that main factor for the reduction of scale of land supply is the high level of transaction costs for organization of farmland within the farm borders. The management of outside deals (sell-off or lease-out contracts) is much more economical than internal integration of transactions through hiring of new workers, providing necessary finance, and organizing new activities on available lands. Farms restricting the internal land supply either minimize the farm size or extend the farm through organization of land-saving transactions (e.g. intensive crops, livestock operations, agricultural services etc.).

Land deals are not only a means for changing the farm size but also a way for rationalization of land organization. In a situation of a significant portioning (scattering) of land ownership ${ }^{12}$ in the country the trade with rights on agricultural land is a major way for consolidation of land plots. Resulting land concentration enhances the farm efficiency. Firstly, it minimizes considerably the technological expenditures (allowing effective exploration of the economy of size and scale from utilization of machinery and equipment, and economy on transportation costs etc.). Secondly, it leads to a significant economy on transacting costs from effective labor direction and supervision, and quality control on contacted services, and lesser needs for security guards etc. Thirdly, it permits farm extension since it increases the possibilities for effective organization of more internal and outside transactions under a single management.

More than $40 \%$ of leasing-out farms simultaneously take part in lease-in transactions, as onethird of them do this "often" (figure 5). Every tenth of leasing-in farms lease-out land as well, and $8 \%$ of them often are involved in such "opposite" transacting. Not small portion of farms 
applying other forms for land supply (such as purchase, sell, lease out, lease in) at the same time practice "compensating" opposite deals (sell, purchase, lease-in, lease-out). This proves, that a part of surveyed farms use effectively different land deals not only for modifying the size, but (mainly) for rationalization of farm's land supply.

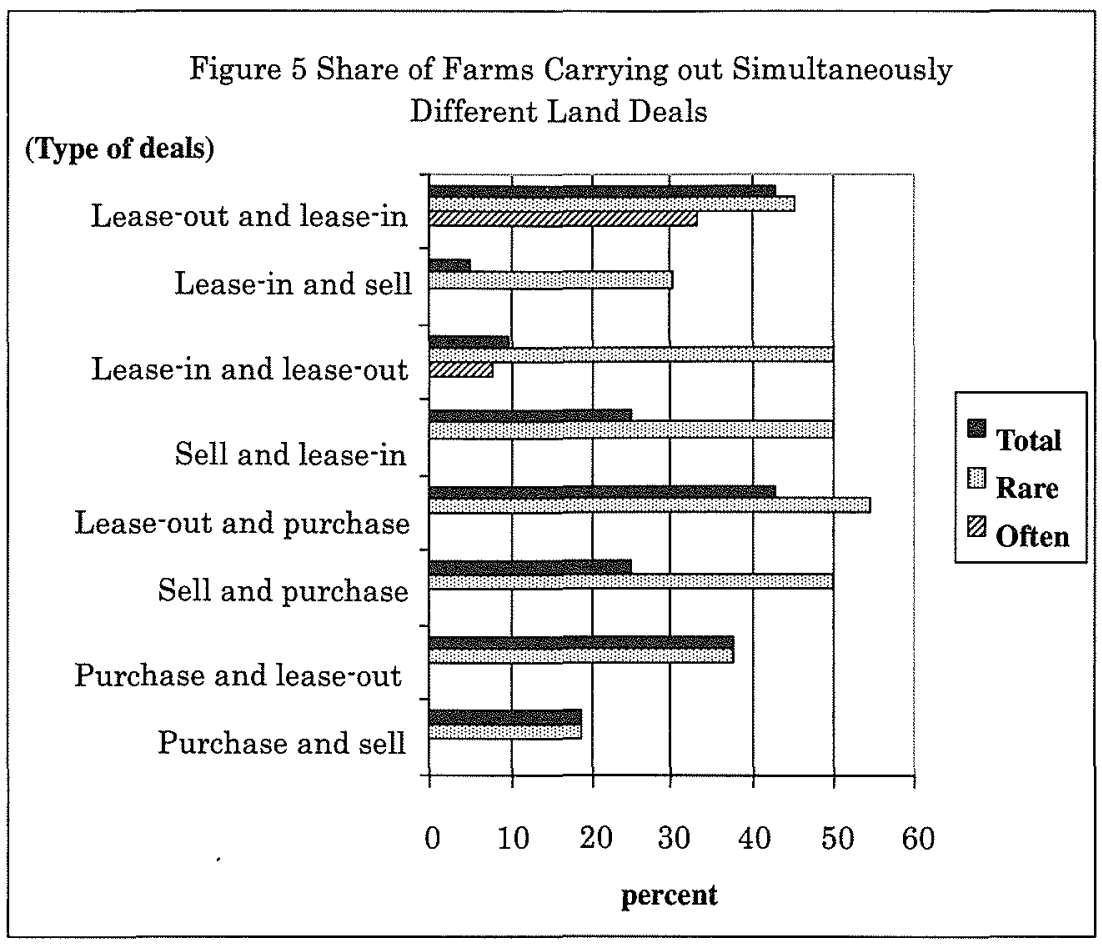

Source: personal interviews

\section{2 Limits of farm expansion}

In Bulgaria two extreme forms for farming and land organization have been dominating for last 14 years until now - numerous small-scale farms and a few large farm enterprises. This is quite opposite to the traditional textbook assumptions where farm borders are determined by the technological parameters (such as possibilities to explore economy of scale and scope). Our research proves, that when transaction costs are high, they block otherwise effective transactions, and restrict farm size far bellow the technologically optimal level. Very often the high costs for market trading (agrarian resources and outputs, finding credit) and/or internal governance (e.g. deficiency of low transacting cost labor) limit the farm size to miniature subsistent farming or family borders. In other instances, existing effective potential to economize on market transacting costs causes a vast extension of farm size through backward, lateral or forward integration of transactions. We have shown how the high costs for market and contract trading after 1990 has turned the subsistent and cooperative farming into the most effective forms for organization of available agrarian assets (farmland, livestock, etc.) of millions Bulgarians. In the same way, 
the enormous costs of (free) market trading have caused a domination of integrated and interlinked modes, and concentration of commercial farming into a few thousands large firms and cooperatives (Bachev and Tsuji 2001b).

Generally, there are two groups of factors, which restrict the enlargement of farms. Firstly, those are the institutional restrains such as formal restrictions to buy or lease-in land up to a certain limit or by certain agents, production and marketing quotas etc. And secondly, those are overall costs for governing of farm related transactions. Accordingly, if breaking up the formal institutional restrictions is associated with high transaction costs (because of the "good enforcement" and "high penalty for offenders"), and/or the governance of transactions under a single management is very expensive (high level of internal and outside transacting costs), the farm size will stay beyond the technologically optimal level.

A major factor limiting farm extension, which is generally identified around the world, is the enormous costs for enforcement (monitoring, measuring, controlling) of non-family labor contracts (Hayami and Otsuka) ${ }^{13}$. According to the estimates of the most of the managers of surveyed commercial farms in Bulgaria, the highest transaction costs are associated with "credit supply", "marketing", and "contract enforcement" (Table 4). Therefore, besides high governing costs for enforcement of labor contracts, other factors restricting farm enlargement of Bulgarian farms are the high contracts enforcement costs in general as well as enormous credit supply and marketing costs. In addition, a good part of cooperative and middle-size farms spend significant "time and efforts" for arranging land supply. For the majority of large farms and firms "finding partners selling or leasing land" takes also a good deal of the overall management efforts.

Almost two-third of Bulgarian commercial farms indicates their intention to "enlarge farm size" in the future, including $91 \%$ of firms, $81 \%$ of large and $66 \%$ of middle-size farms, $59 \%$ of unregistered and small farms, and $46 \%$ of cooperatives. For majority of surveyed farms the "main factors for development of their farms" relate to improvement of institutional environment - "guaranteed marketing", "enforcement of Laws and private contracts", "macro-economic stability", "legislation framework", and "access to free markets". Accumulated specific capital in form of "own and family experience" receives also a high priority. Furthermore, there are no specific factors associated with land supply, which could impede the farm development in the future. This is a consequence of the abundance of "cheap" farmland as unused land currently reaches one-fifth of the agricultural land in the country. Besides, along with the development of markets (competition) and welfare of rural population there will be additional releases of land from subsistent and small-scale farming. This farmland will be available for cheap land supply, and eventually transferred to more effective governing structures. 
Table 4 Time and Efforts for Governing of Different Farm Transactions (percent)

\begin{tabular}{|c|c|c|c|c|c|c|c|c|}
\hline \multirow{2}{*}{$\begin{array}{l}\text { Efforts and time } \\
\text { for: }\end{array}$} & \multirow[t]{2}{*}{ Level } & \multicolumn{7}{|c|}{ Kind of farms } \\
\hline & & Unregistered & Cooperative & Firms & Small & Middle & Large & Total \\
\hline \multirow{2}{*}{$\begin{array}{l}\text { Finding new } \\
\text { workers }\end{array}$} & big & 18.91 & 14.28 & 12.5 & 18.91 & 18.18 & 0 & 15.46 \\
\hline & average & 8.10 & 42.85 & 37.5 & 5.40 & 45.45 & 31.25 & 27.83 \\
\hline \multirow{2}{*}{$\begin{array}{l}\text { Finding partners } \\
\text { selling or } \\
\text { leasing out } \\
\text { farmland }\end{array}$} & big & 18.91 & 35.71 & 12.5 & 13.51 & 31.81 & 12.5 & 21.64 \\
\hline & average & 29.72 & 14.28 & 62.5 & 18.91 & 40.90 & 62.5 & 36.08 \\
\hline \multirow{2}{*}{$\begin{array}{l}\text { Finding suppliers } \\
\text { for needed } \\
\text { materials, } \\
\text { equipment etc. }\end{array}$} & big & 24.32 & 21.42 & 50 & 21.62 & 34.09 & 50 & 31.95 \\
\hline & average & 29.72 & 67.85 & 25 & 35.13 & 45.45 & 31.25 & 39.17 \\
\hline \multirow{2}{*}{$\begin{array}{l}\text { Finding markets for } \\
\text { outputs }\end{array}$} & big & 37.83 & 42.85 & 56.25 & 27.02 & 56.81 & 56.25 & 45.36 \\
\hline & average & 13.51 & 35.71 & 28.12 & 27.02 & 20.45 & 31.25 & 24.74 \\
\hline \multirow{2}{*}{$\begin{array}{l}\text { Finding the rest of } \\
\text { needed information }\end{array}$} & big & 45.94 & 17.85 & 15.62 & 40.54 & 18.18 & 25 & 27.83 \\
\hline & average & 10.81 & 21.42 & 40.62 & 8.10 & 31.81 & 37.5 & 23.71 \\
\hline \multirow{2}{*}{$\begin{array}{l}\text { Negotiating and } \\
\text { preparing contracts }\end{array}$} & big & 18.91 & 35.71 & 40.62 & 16.21 & 40.90 & 37.5 & 30.92 \\
\hline & average & 27.02 & 21.42 & 37.5 & 21.62 & 27.27 & 50 & 28.86 \\
\hline \multirow{2}{*}{$\begin{array}{l}\text { Controlling } \\
\text { implementation of } \\
\text { contractual terms }\end{array}$} & big & 48.64 & 42.85 & 37.5 & 45.94 & 36.36 & 56.25 & 43.29 \\
\hline & average & 5.40 & 14.28 & 31.25 & 5.40 & 22.72 & 25 & 16.49 \\
\hline \multirow{2}{*}{$\begin{array}{l}\text { Resolving conflicts } \\
\text { associated with } \\
\text { quality and } \\
\text { contracts }\end{array}$} & big & 29.72 & 14.28 & 99.37 & 29.72 & 31.81 & 56.25 & 35.05 \\
\hline & average & 5.40 & 50 & 21.87 & 16.21 & 31.81 & 18.75 & 23.71 \\
\hline \multirow{2}{*}{$\begin{array}{l}\text { Relations with } \\
\text { banks and } \\
\text { preparing projects } \\
\text { for crediting }\end{array}$} & big & 35.13 & 42.85 & 59.37 & 32.43 & 42.72 & 68.75 & 45.36 \\
\hline & average & 8.10 & 42.85 & 37.5 & 5.40 & 45.45 & 31.25 & 16.49 \\
\hline \multirow{2}{*}{$\begin{array}{l}\text { Associating with } \\
\text { registration regimes }\end{array}$} & big & 18.91 & 17.85 & 15.62 & 18.91 & 18.18 & 12.5 & 17.52 \\
\hline & average & 2.70 & 21.42 & 9.37 & 10.81 & 13.63 & 0 & 10.30 \\
\hline \multirow{2}{*}{$\begin{array}{l}\text { Relations with } \\
\text { administration }\end{array}$} & big & 24.32 & 10.71 & 18.75 & 21.62 & 15.90 & 18.75 & 18.55 \\
\hline & average & 21.62 & 42.85 & 40.62 & 32.43 & 38.63 & 25 & 34.02 \\
\hline \multirow{2}{*}{$\begin{array}{l}\text { Relations with } \\
\text { membership } \\
\text { organizations }\end{array}$} & big & 18.91 & 21.42 & 6.25 & 16.21 & 20.45 & 0 & 15.46 \\
\hline & average & 5.40 & 25 & 43.75 & 2.70 & 40.90 & 25 & 23.71 \\
\hline \multirow[t]{2}{*}{ Others } & big & 5.40 & 14.28 & 0 & 0 & 15.63 & 0 & 6.18 \\
\hline & average & 0 & 0 & 0 & 0 & 0 & 0 & 0 \\
\hline
\end{tabular}

Source: personal interviews 


\section{Conclusions}

Land supply is indispensable for most of agricultural activities and a major form for enlargement of (crop) farms. However, the efficiency of governing modes for land supply cannot be properly understood within the traditional "Neoclassical Economics" framework (production costs reason) or in the narrow borders of "agency relations" (agency costs reason).

Our comparative institutional and transaction cost analyses explains why evolving governing structure of land supply is quite different from the "textbook logic" of the traditional agrarian economy. It allows to understand the high "efficiency" and complementarities of evolving modes for land supply in transitional conditions such as: consistent farming, ownership integration, provisional lease-in contracts, undeveloped sell markets, cooperation and interlinked organizations etc. Besides, it raises and answers questions which remain off the traditional studies of tenant relations - for the total "costs" of alternative forms for land supply, for sustainability and complementarities of different governing forms, for institutional and microeconomics factors for preferences to a particular mode of transactions, for the effective farm boundaries and prospects of farm development in the specific (economic, institutional, cultural, and natural) environment etc.

This new approach could assist substantially agrarian policy and business strategy formation. Microanalysis of transacting attributes and costs could improve significantly the farm management and the design of efficient modes of transacting. Public (Government, EU, local authority, NGO's etc.) intervention and support to agrarian sphere could also be considerably rationalized through analyses of the transactions costs and prospective ways for their minimization.

Incorporation of the New Institutional and Transaction Costs Economics into analyses of transforming agriculture should continues through including new critical factors of transaction costs, identification of new forms for governing of land supply and increasing representation of case studies etc.

\footnotetext{
Notes

'In Bulgaria, there is no commonly accepted system for classification of farms as small, medium, or big. In this study we use self-determination (perception, assessment) of farm managers for grouping the farms. Managers have all necessary information to make an accurate assessment of their farms according to dominant regional, subsector, industry etc. standards, and community and social perception of different farms.

' Until 1995 all assets of previous cooperatives were distributed into individual shares and transferred into new private structures, and management of almost entire cultivated land were in private hands.

"Forbidden by the Antimonopoly and Land Laws (restrictions for land lease were abandoned in 1999).

"Process of initiation, identification, and practical execution of private property right restoration on agrarian resources (land and material assets) has been associated with enormous social and individual costs (Bachev 2000).

'After 1991 there emerged around 1.8 million farms - as many as the number of new land owners (National Statistical Institute).

"Sells deals on agricultural land has raised several folds since 1999 (System of Agro-market Information). Nevertheless, sold land still constitutes a small portion of total arable (1.19\%) and entire agricultural land $(0.95 \%)$

While short-term (and most recently) long-term public credits are becoming available through various support
} 
programs (State Fund Agriculture, SAPARD), for participating in public projects there is an explicit requirement to possess the needed farmland.

"However, widespread application of short-lease have created serious problems in some regions of the country - not observing crop-rotation, soil and water pollution, inadequate compensation of extracted from soil N,P and $K$, abandoning of large areas of productive lands etc.

" 2000 changes in Cooperative Law have ruled out possibility for cooperatives to own farmland, and thus entire land supply of cooperatives comes through lease-in contracts.

${ }^{13}$ In fact a land bank was set up at the Ministry of Agriculture and Fishery in 1999 with a goal to facilitate land transfers. However, it has not been commonly used by interested partics.

${ }^{11}$ In some cases, those are illegal means to enforce contracts.

12 After 1991 almost 1.8 million previous owners got restituted their lands in 12 millions small lots usually dispersed in large areas. No land consolidation has followed after restoration of property rights, despite that it has been discussing all the time.

1: This is why owner-operated farm is the most common form for farm organization around the world.

\section{References}

Bachev H. (2000): Bulgarian Experience in Transformation of Farm Structures, in Farm Management and Rural Planning I, Kyushu University, Fukuoka

Bachev H. (2002): Restructuring of Bulgarian Agriculture, in M. Kagatsume et al. Agricultural Restructuring and Environmental Issues in Eastern Europe under the Transition Process, Graduate School of Agriculture, Kyoto University, Kyoto

Bachev H. and M.Kagatsume (2002): Governing of Financial Supply in Bulgarian Farms, The Natural Resource Economics Review, No 8, Kyoto University, Kyoto

Bachev H. and M.Kagatsume (2003): Governing of Output utilization in Bulgarian Farms, The Natural Resource Economics Review, No 9, Kyoto University, Kyoto

Bachev H. and M.Tsuji (2001a): Goveming of Agrarian Transactions, in Farm Management and Rural Planning II, Kyushu University, Fukuoka

Bachev H. and M.Tsuji (200lb): Structures for Organization of Transactions in Bulgarian Agriculture, Journal of the Faculty of Agriculture of Kyushu University, No 46 (1), Fukuoka

Hayami Y. and K. Otsuka (1993): The Economics of Contract Choice. An Agrarian Perspective, Clarendom Press, Oxford

OECD (2000): Review of Agricultural Policies in Bulgaria, Paris

Williamson O. (1996): The Mechanisms of Governance, New York, Oxford University Press 


\section{Abstract}

In this paper an attempt has been made to identify dominant forms and factors for land supply in Bulgarian farms. The New Institutional and Transaction Costs Economics framework is adopted to transitional agrarian economy. Institutional, behavioral, and transaction costs factors for evolution and sustainability of different forms of subsistent, cooperative, and commercial land supply in Bulgaria have been analyzed. Comparative efficiency of various forms for land supply in market-oriented farms of different type (unregistered, cooperatives, agro-firms) and sizes (small, middle, large) has been estimated. The study is based on original microeconomics data collected through interviews with managers of $0.5 \%$ of commercial farms in the country.

First of all, a general characteristics and development of different kind of farms in Bulgaria has been presented. This analysis comprises: the kind of new commercial farms; the type of transactions under their management; the pace of evolution of market oriented farms; and factors for emergence of large-scale subsistent farming. Institutional and transaction costs origin of existing forms of farming has been underlined.

Secondly, an analysis is made on major modes for land supply in commercial farms. It includes: the type of land supply (e.g. own land, leased land, cultivation in groups); modes of acquisition of land ownership (restitution, privatization, purchase); extent of lease-in contracts; forms for reduction of land "supply" (sell off and lease-out land). Dominating modes of land supply are found to relate to critical dimensions and costs of transacting.

Thirdly, an analysis of the transaction costs in land supply has been made. It encompasses: the specific features of land supply contracts; the type of rent; extent of a third-party involvement in land transactions; and problems in land supply deals. Preferred contract forms depend on attributes of transactions and aim at protecting and minimizing costs of land deals.

Finally, factors for enlargement of Bulgarian farms have been specified. It is proved that the reduction of land supply and the expansion of size of commercial farms, both have been determined by the transaction costs reasons. Presently, the high marketing, credit supply, and contract enforcement costs are the major factors restricting farms enlargement. A good part of cooperatives and middle-size farms also spend significant "time and efforts for finding partners selling or leasing-out land" On the other hand, the most important factor for farm development in the future relates to improvement of the institutional environment, and managerial experience of farm entrepreneurs. According to the farm managers there are no specific factors related to land supply which could impede farm development in the country.

Key words: governing of land supply, New Institutional and Transaction Costs Economics, transitional farm organization

（受理日 2005年1月31日） 